УДК $94: 327(477+438)$

DOI: https://doi.org/10.33782/eminak2019.2(26).300

\title{
СТАНОВЛЕННЯ ТА РОЗВИТОК УКРАЇНСЬКО-ПОЛЬСЬКИХ ВІДНОСИН У ГЕОПОЛІТИЧНОМУ ПРОСТОРІ НАПРИКІНЦІ ХХ - ПОЧАТКУ ХХІ СТ.
}

\author{
Ігор Дацків \\ Тернопільський національний економічний університет (Тернопіль, Україна) \\ e-mail: idatskiv@ukr.net \\ ORCID: https://orcid.org/0000-0001-8359-3937
}

Розглянуто питання міжнародної співпраці між Україною та Республікою Польща; узагальнено напрями дипломатичної взаємодії між ними й обгрунтовано принципи за якими будуються добросусідські відносини між цими двома державами.

Встановлено, що українсько-польські відносини, які набули характеру стратегічного партнерства, утверджувалися поступово, відповідно до національних інтересів і викликів сучасного облаштування світоустрою.

Показано, що по мірі становлення нової моделі взаємин України та Польщі їі політична складова є ключовою. Інтенсивність політичних відносин забезпечується на дипломатичному, міжурядовому, міжпарламентському рівнях, у контактах між Президентами та громадськими об'єднаннями.

Ключові слова: Україна, Республіка Польща, відносини, співпраця, зовнішня політика

3 початком XXI ст. країни Центральної та Східної Європи вступили у новий період розвитку міжнародних відносин, обумовлений радикальними реформами та масштабними змінами геополітичної парадигми. 3 одного боку, глобальні трансформаційні перетворення у більшості країн посткомуністичного простору призвели до встановлення правового устрою на основі політичного плюралізму. Набуття демократичних форм суспільно-політичного, соціально-економічного та гуманітарного розвитку дозволило їм прискорити розвиток та успішно інтегруватися до євроатлантичної спільноти.

Відтак, посилення інтересу історичної науки до дослідження українськопольських відносин у новітній геополітичній системі стало закономірною вимогою часу. Зокрема й через те, що зовнішньополітичний курс «багатовекторності», характерний для перших двох десятиліть незалежності, на нинішньому етапі все більшою мірою не відповідає своїм основним функціям і демонструє усе меншу спроможність ефективно відповідати на актуальні виклики, зокрема у ході вирішення й усунення насущних проблем міждержавних, міжнародних і міжнаціональних відносин. Наочним прикладом тому є наростання агресивності у зовнішній політиці Російської Федерації щодо пострадянських країн, які обрали проєвропейський шлях розвитку.

Актуалізація дослідження двосторонніх відносин між Україною та Республікою Польща обумовлена також тим, що ці країни мають багатовікове спільне історичне минуле, значну протяжність спільного кордону, чисельну українську національну меншину в Республіці Польща та польську - в Україні, тісні культурні зв'язки.

Упродовж 1990-х рр., реалізуючи зовнішньополітичну програму, схвалену Верховною Радою України та затверджену Президентом, українське дипломатичне відомство визначило основні напрями та пріоритети, сформулювало цілі та завдання своєї діяльності, намітило коротко- та довгострокові перспективи. Попри те, що Україна 
проводить політику на розбудову відносин із численними країнами Європи та світу, розвиток багатоаспектних взаємин із Польщею носить пріоритетний характер.

Становлення відносин між Україною та Республікою Польща, як незалежних держав, стало можливим завдяки змінам в Європі наприкінці XX - на початку XXI ст. Взаємини між обома державами набули нового виміру та поступово переросли у тісне політичне, економічне, наукове та культурне співробітництво, що характеризується нині як стратегічне партнерство.

Співпраця між Україною та Польщею почала формуватись, зважаючи на тривалу історичну традицію, географічні, історичні, культурні та демографічні чинники, що продовж століть зближували ці держави і народи.

Взаємини українського та польського народів мають багатовікову і трагічну історію. У минулому були приклади добросусідства, спільної боротьби з ворогами, звичайно й те, про що не хотілося б згадувати, але історію не перепишеш. ХХ ст. було періодом реалізації національних інтересів наших народів, що породжувало конфлікти і драматичні події, які на сьогоднішній день створили психологічний бар'єр у вигляді синдрому упередженості негативних стереотипів, а то й проявів ворожості. Особливо закарбувалися у пам'яті трагічні події останньої світової війни та повоєнних років.

Нині на порозі XXI ст. Україна та Республіка Польща здобули можливість творити власну долю у мирних і демократичних взаємовідносинах, як кожний окремо, так і разом як сусіди. На сучасному етапі розвитку людського суспільства, що має перехідний характер, саме на співпраці, а не на взаємних звинуваченнях можна вирішувати проблеми міжнародної безпеки, ліквідації загрози воєнних конфліктів, вирішення екологічних проблем, допомоги бідним народам. Адже й Україна, й Польща, як найбільші країни Центрально-Східної Європи, мають досвід і ресурси співпраці у галузі державної влади, місцевого самоврядування, господарства, торгівлі, розв'язання паливно-сировинних та екологічних проблем, зовнішньої й оборонної політики з метою створення ефективної системи європейської безпеки, науки, культури, освіти, покращення статусу етнічних і релігійних меншин на підставі міжнародного права та демократії.

Загалом необхідність розбудови міждержавних відносин між Україною та Республікою Польща обумовлювались об'єктивними потребами та національними інтересами і відображалися у концепціях зовнішньої політики обох держав.

Українсько-польські відносини виходять за рамки двостороннього співробітництва, бо геополітична ситуація об'єднала держави у визначенні єдиного зовнішньополітичного курсу - інтеграція до європейських структур. У 1996 р. партнерство обох держав було визначене як стратегічне. Сьогодні найважливішим результатом партнерства $є$ те, що на рівні національних еліт досягнуте взаєморозуміння у важливості налагодження добросусідства і несприйняття давніх взаємних претензій та образ. Історія українсько-польських відносин кінця XX - початку XXI ст. досі недостатньо досліджена на науковому рівні. У даний період історії події розвивалися настільки динамічно та драматично, що об’єктивно породили розходження в оцінках.

Метою даної статті є об'єктивний аналіз розвитку українсько-польських відносин з моменту отримання Україною незалежності і до цього часу. У статті, відповідно до даної мети, поставлені наступні завдання: розкрити основні напрями співпраці; дати характеристику сучасного стану відносин України з країнами Європи взагалі та з Польщею зокрема; проаналізувати динаміку розвитку міждержавних відносин; 
намітити основні шляхи розвитку відносин, дати рекомендації по їх вдосконаленню.

Серед українських науковців, які зробили внесок у вивчення досліджуваних нами питань можна виділити праці Л.Зашкільняка та М.Крикуна ${ }^{1}$, Л. Стрільчук²,

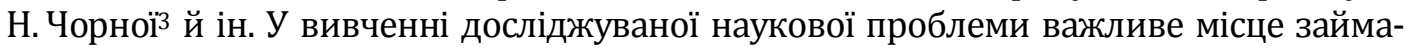
ють тематичні збірники загального характеру, зокрема «Україна в міжнародних відносинах з країнами Центральної та Південно-Східної Європи»4, «Україна і Польща стратегічне партнерство. Історія. Сьогодення. Майбутнє» 5 , «Україна на міжнародній арені»6 й ін. У цих виданнях вміщено різноманітні матеріали про глибокі трансформації європейського геополітичного простору, що мали місце наприкінці XX ст. й обумовили початок нового етапу українсько-польських взаємин, розглянуто основні етапи співпраці обох сторін і чинники, що на неї впливають.

Окремою групою в опрацьованій історіографії доречно виділити праці польських дослідників, серед яких особливо вартісними $\epsilon$ дослідження Я.Драуса7, В. Зайончковського ${ }^{8}$, Б. Бердичовської ${ }^{9}$ й ін.

Формування міждержавних взаємин між Україною та Республікою Польща відбувалися у несприятливих історичних умовах. Після Другої світової війни обидві країни опинилися у сфері впливу Радянського Союзу, і з цього випливає, що офіційні контакти між нашими державами у цей період були мінімальними. Проте доречно зазначити, що Україна будучи активним учасником радянсько-польського співробітництва, активно брала участь у співпраці між українськими та польськими підприємствами, а саме: Київське об’єднання «Електронмаш» і польська фірма «Матронекс»; заводи «Ура» і «Мера-Зап» у Польщі та Підприємство кранів в Одесі; Львівське об’єднання «Електрон» і Варшавський завод телевізорів.

Не можна обійти увагою і співпрацю у культурних і наукових сферах. Досить тісно співпрацювали університети Києва та Кракова, Львова і Любліна, Харкова і Вроцлава, Тернополя і Жешува, між двома державами діяли науково-дослідні інститути: електрозварювання, кібернетики, ядерної фізики, біології, історії10.

Починаючи з 1989 р. в Польщі та Європі відбулися революційні зрушення: розпад РЕВ (Ради економічної взаємодопомоги), Варшавського договору, перші демократичні вибори та прихід до влади демократичного уряду. Ці події сприяли тому, що

\footnotetext{
1 Зашкільняк Л.О., Крикун М.Г. Історія Польщі: від найдавніших часів до наших днів. Львів, 2002. $752 \mathrm{c}$.

${ }^{2}$ Стрільчук Л.В. Україна - Польща: від добросусідських відносин до стратегічного партнерства (кінець XX - початок XXI ст.): монографія. Луцьк: Волинські старожитності, 2013. 607 с.

з Чорна Н. Україна і Польща: історіографія відносин (кін. XX - поч. XXI ст.). Вінниця: ПП Балюк І.Б., 2014. $416 \mathrm{c}$.

4 Україна в XX столітті (1900-2000рр.): в 2-хч. Ч. 1. Україна в міжнародних відносинах з країнами Центральної та Південно-Східної Європи. Анот. іст. хроніка / Від. ред. С.В. Віднянський. Київ: Ін-т історії України НАН України, 2001. 310 с.

5 Україна і Польща - стратегічне партнерство. Історія. Сьогодення. Майбутнє: Зб. наук. пр. / Таїсія Зарецька (заг. ред.). Ч. 2. Київ, 2002. 238 с.

6 Україна на міжнародній арені. Київ: Юрінком Інтер, 1998. Кн. 1. / В.В.Будяков (упоряд.); Г.Й. Удовенко (ред.). Київ, 1998. 734 с.

7 Драус Я. Дослідження польсько-українських стосунків у 1991-2008 роках: нарис проблематики // Чорноморський літопис. Науковий журнал. 2010. Випуск 1. С. 32-41.

8 Зайончковський В. Восточная Европа в польской дипломатии // Pro et Contra. 1998. Т. 3. № 2 (весна). С. 39-52.

9 Berdychowska B., Wujec H. Idee spuszczone ze smyczy.W rocznice Aktu Niezaleznosci Ukrainy // Gazeta Wyborcza. 2010. 24 sierpnia.

10 Україна і Польща - стратегічне партнерство. Ч. 2... С. 130.
} 
Польща почала самостійно торувати шлях до нових суспільно-політичних і економічних відносин, тобто відбулося формування нової Польщі11.

16 липня 1990 р. Верховна Рада УРСР прийняла «Декларацію про державний суверенітет», а вже 28 липня того ж року Сейм Республіки Польща утвердив ухвалу, в якій привітав прийняття Верховною Радою УРСР Декларації про державний суверенітет, як вираз прагнення України до незалежності. В Ухвалі також мовилося про бажання поляків співіснувати з українцями як рівними та близькими ${ }^{12}$. Відтак, у посткомуністичній Польщі відбувся процес офіційного перегляду власної історичної політики щодо східних сусідів, насамперед до України.

На міждержавний рівень відносини між Україною і Республікою Польща вивів візит до Києва 13 жовтня 1990 р. міністра закордонних справ Польщі Кшиштофа Скубішевського. Була підписана українсько-польська Декларація про дружбу і співпрацю, котра містила усі ознаки міждержавного договору. У Декларації сторони заявляли про своє прагнення до утвердження між ними як суверенними державами добросусідських відносин, про підтримання та розвиток взаємовигідної співпраці13.

1 грудня 1991 р. уряд України виніс питання про підтвердження Акту про незалежність на всенародне обговорення. 2 грудня Республіка Польща була першою державою, яка визнала незалежність України.

Отже, проголошення незалежності України та зміни у глобальному геополітичному становищі на початку 1990-х років, а також подолання біполярності міжнародних відносин створили специфічні умови переходу дипломатичної діяльності України та Республіки Польща на новий рівень ${ }^{14}$.

Одним із нагальних питань, яке постало перед незалежними урядами, було налагодження міждержавних відносин, яке б посприяло визначенню пріоритетів майбутнього зовнішньополітичного курсу держави.

Протягом першої половини 1990-х років, реалізуючи зовнішньополітичну програму, схвалену Верховною Радою України, українське дипломатичне відомство все таки визначило основні напрями та пріоритети, сформулювало цілі та завдання своєї діяльності, намітило коротко-та довгострокові перспективи.

Після проголошення незалежності України стосунки між українцями та поляками набули нового позитивного імпульсу. У своєму подальшому розвитку, виходячи із національних інтересів обох незалежних держав, ці відносини суттєво впливають на стан регіональної безпеки.

Принципи дипломатичних відносин України з Польщею поступово закріплювалися у Конституції України, в Законах України «Про державну службу», «Про дипломатичну службу», у Віденській Конвенції про дипломатичні зносини 1961 р., у Віденській Конвенції про консульські зносини 1963 р. та ін..$^{15}$.

За ствердженням Вацлава Чігака відносини між Україною та Республікою Польща засновані були на п'ятьох чинниках, спільних для обох теренів, а саме: $\begin{array}{lll}\text { 1) Стратегічно-географічному; } & \text { 2) Політично-оборонному; } & \text { 3) Економічно- }\end{array}$

\footnotetext{
11 Україна на міжнародній арені. Кн. 1... С. 16.

12 Україна в сучасному геополітичному вимірі: теоретичні і прикладні аспекти / За ред. Ф.М. Рудича. Київ: МАУП, 2002. С. 226.

13 Україна і Польща - стратегічне партнерство. Ч. 2... С. 334.

14 Україна в сучасному геополітичному вимірі... С. 75.

15 Там само. С. 75-76.
} 
господарському; 4) Соціально-демографічному; 5) Традиційно-історичному16.

Отже, обидві держави в нових геополітичних реаліях трансформованої Європи прагнули до відносин приязного та взаємовигідного характеру. Фактично саме на цьому етапі закладалися ті передумови для подальшого конструктивного розвитку українсько-польських відносин, які надалі дозволили їм вийти на рівень порозуміння та стратегічного партнерства.

Важливим етапом у формуванні нової системи двостороннього співробітництва став перший офіційний візит Президента України Л. Кравчука до Республіки Польща у травні 1992 р. Він започаткував традицію українсько-польських зустрічей на найвищому рівні. Під час візиту - 18 травня 1992 р. - було укладено базовий договір про добросусідство, дружні відносини та співробітництво між двома державами.

Наступним кроком у поглибленні двосторонніх зв'язків став офіційний візит в Україну Президента Польщі Л. Валенси 24-25 травня 1993 р. Одним із головних його результатів було створення Консультаційного комітету Президента України та Президента Республіки Польща, метою якого стало поліпшення координації спільних дій у галузі транскордонного співробітництва. Перші засідання Консультаційного комітету відбулися наприкінці травня (Київ) і в листопаді (Варшава) 1993 р. Хоча офіційно, як своєрідний механізм «гарячих ліній» між президентами, він почав діяти за обопільною згодою ще з квітня 1993 р.17.

Позицію Польщі щодо України чітко сформулював під час візиту до Києва 911 лютого 1994 р. міністр закордонних справ Республіки Польща Б. Геремек: «Наш інтерес полягає в посиленні незалежності України і Білорусі, інакше Польща стане останньою фортецею, «полем битви» між Сходом і Заходом, що було б для нас невигідно»18. Тому в ході зустрічі навіть було висунуто ініціативу щодо включення України до франко-німецько-польської парламентської співпраці у межах «Веймарської групи»

Відтак, під час візиту-відповіді міністра закордонних справ України А. Зленка до Варшави у березні 1994 р., було прийнято Декларацію міністрів закордонних справ України та Республіки Польща про засади формування українсько-польського партнерства, де особливо наголошувалося на європейському контексті двосторонніх відносин.

Україну також цікавила повноцінна робота у структурах Центральноєвропейської ініціативи (ЦЄІ), асоційованим членом якої вона була з 1994 р. Польща, яка на той час головувала в ЦЄІ, підтримала це прагнення України під час зустрічі міністрів закордонних справ країн - членів ЦЄІ у Кракові в квітні 1995 р. і двосторонніх українсько-польських консультацій у Варшаві в липні 1995 р.19.

Загалом уже з 1994-1995 рр. Польща певним чином стала виконувати «цивілізаційну місію» щодо України - представляла інтереси нашої держави на міжнародній арені. Водночас можна говорити про певну пасивність в українсько-польських відносинах у період 1993-1995 рр. Відтак, керівництво Республіки Польща не дало згоди на допомогу Україні щодо входження до Вишеградської групи та в реалізації проекту створення зони безпеки та стабілізації у Центрально-Східній Європі, пропаговане Президентом України Л. Кравчуком 1993 р. Реалізуючи свої зовнішньополітич-

\footnotetext{
16 Україна і Польща - стратегічне партнерство. Ч. 2... С. 335-336.

17 Чекаленко Л.Д. Зовнішня політика України. Київ: Либідь, 2006. 712 с.

18 Чорна Н. Вказ. пр. С. 284.

19 Чекаленко Л.Д. Вказ. пр. С. 40.
} 
ні пріоритети, орієнтовані на розвиток відносин із Брюсселем, Польща приєдналась до позиції Заходу про ядерне роззброєння України ${ }^{20}$.

Українсько-польські відносини вийшли на рівень стратегічного партнерства після підписання Президентами - Л. Кучмою та А. Квасьневським - Спільної заяви «До порозуміння і єднання» у травні $1997 \mathrm{p}$.

Стратегічне партнерство означає, насамперед, співзвуччя позицій з основних питань міжнародної безпеки та інтеграції з європейськими та євроатлантичними структурами. Як результат, активізувалися контакти на всіх рівнях - загальнодержавному, міжгалузевому, підприємницькому, науковому, культурному. Пожвавив свою роботу також Консультаційний комітет. На нього було покладено функції координатора всіх видів українсько-польського співробітництва.

Водночас, наприкінці XX ст. відносини між Україною та Польщею стали дещо прохолоднішими. Серед причин, що призвели до такої ситуації, можна назвати активізацію українсько-російських взаємин. Зокрема, 26 травня 1997 р. було підписано «Великий договір» між Києвом і Москвою, через що сформувалася думка про Україну як таку, що наближена до Росії. Польща, зі свого боку, також намагалася розвивати активні відносини з Російською Федерацією, оскільки є залежною від російських енергоносіїв 21.

Загалом визначальними чинниками становлення українсько-польських відносин були геополітичні зміни останнього десятиріччя XX ст., а саме: подолання протиборства Схід-Захід, падіння комунізму, переорієнтація низки держав на засади цінностей демократії. Крах СРСР і поява на світовій арені нових незалежних гравців, пострадянських держав, започаткували у світовому співтоваристві переоцінку цінностей і руйнацію тривалого домінування Росії на «євразійському просторі».

Як і Україна, так і Республіка Польща здобули незалежність і стали окремими, повноправними суб'єктами міжнародного права. У зв'язку з цим, оскільки обидві країни $€$ найближчими сусідами, почали будуватись стратегії майбутніх міждержавних взаємин, зважаючи на переоцінку історичних і геополітичних чинників. Держави зуміли знайти спільну єдність і започаткували перші сторінки своїх відносин на демократичних засадах, без претензій на території і впродовж багатьох наступних років напрацювання, що відбулися за цей період, вилились у співпрацю рівня стратегічного партнерства.

Таким чином, підтримка та розвиток рівня партнерства між Україною та Польщею значно залежить від збереження нинішніх політичних контактів, зміцнення суспільного діалогу, а також успіху реформаторської політики в Україні. Отже, незважаючи на наявність багатьох проблемних моментів, у загальному українськопольські відносини мають хорошу динаміку розвитку. За умови дотримання послідовного зовнішньополітичного курсу двома державами зміцнення двосторонніх взаємин спроможне допомогти Україні укріпити власні позиції на міжнародній арені, сприятиме зміцненню економіки та європейській інтеграції.

\section{REFERENCES}

Berdychowska B. \& Wujec H. (2010, 24 sierpnia). Idee spuszczone ze smyczy.W rocznice Aktu Niezaleznosci Ukrainy. Gazeta Wyborcza [in Polish].

Birkovich, T.I. (2009) Pryntsypy dyplomatychnyh vidnosyn mizh Ukrainoiu ta Polscheiu u suchasnii

20 Berdychowska B., Wujec H. Ibidem.

21 Meszka A. Ibidem. 
period [Principles of diplomatic relations between Ukraine and Poland in the modern period. $\mathrm{Hu}$ manitarni nauky, 1, 75-78 [in Ukrainian].

Chekalenko, L.D. (2006). Zovnishnia polityka Ukrainy [Ukraine's foreign policy]. Kyiv: Lybid [in Ukrainian].

Chorna, N. (2014). Ukraina i Polscha: istoriohrafiia vidnosyn (kinets XX - pochatok XXI st.) [Ukraine and Poland: historiography of relations (the end of the XXth - the beginning of the XXI century)]. Vinnytsia: PP Balyuk I.B. [in Ukrainian].

Draus, Ya. (2010). Doslidzhennia polsko-ukrainskyh stosunkiv u 1991-2008 rokah: narys problematyky [Polish-Ukrainian Relations in 1991-2008: An Essay on Problems]. Chornomorskyi litopys: naukovyi zhurnal, 1, 32-41 [in Ukrainian].

Rudych, M, (Ed.). (2002). Ukraina v suchasnomu heopolitychnomu vymiri: teoretychni i prykladni aspekty [Ukraine in the modern geopolitical dimension: theoretical and applied aspects]. Kyiv: MAUP [in Ukrainian].

Strilchuk, L.V. (2013). Ukraina - Polscha: vid dobrosusidskyh vidnosyn do stratehichnoho partnerstva (kinets XX - pochatok XXI st.) [Ukraine-Poland: From Good-Neighbourly Relations to Strategic Partnership (end of the $20^{\text {th }}$ - beginning of the $21^{\text {st }}$ century)]. Lutsk: Volynski starozhytnosti [in Ukrainian].

Ukraina v XX stolitti (1900-2000 rr.) (2001). Ch. 1. Ukraina v mizhnarodnyh vidnosynah z krainami Tsentralnoi ta Pivdenno-Shidnoi Evropy [Ukraine in the XX century (1900-2000): Part 1. Ukraine in international relations with the countries of Central and Southeast Europe]. Kyiv: NAN Ukrainy [in Ukrainian].

Ukraina i Polscha - stratehichne partnerstvo. Istoriia. Sohodennia. Maibutne (2002). [Ukraine and Poland are strategic partnerships. History. Present. Future]. Kyiv [in Ukrainian].

Ukraina na mizhnarodnii areni (1998). [Ukraine on the international scene]. Kyiv [in Ukrainian].

Vasilev, D. (1998). Ukrainsko-polski vidnosyny naprykintsi XX st. [Ukrainian-Polish relations at the end of the XX century]. Nova politika, 4, 13-17 [in Ukrainian].

Zaionchkovskyi, V. (1998). Vostochnaia Evropa v polskoi diplomatii [Eastern Europe in Polish diplomacy]. Pro et Contra, 3, 2, 39-52 [in Russian].

Zashkilniak, L.o. \& Krykun, M.G. (2002). Istoriia Polschi: vid naidavnishyh chasiv do nashyh dniv [History of Poland: from ancient times to the present day]. Lviv [in Ukrainian].

\author{
Ihor Datskiv \\ (Ternopil National Economic University, Ternopil, Ukraine) \\ ORCID: https://orcid.org/0000-0001-8359-3937
}

\title{
Establishing and Development of Ukraine-Poland Relations in the Geopolitical Space at the end of the $19^{\text {th }}$ - beginning of the $21^{\text {st }}$ century
}

The issues of international cooperation between Ukraine and the Republic of Poland are considered; the trends of diplomatic interaction between them are generalized and the principles of establishing good-neighborly relations between these two states are grounded.

It is found out that the Ukraine-Poland relations, which has become strategic partnerships, were establishing gradually, in accordance with national interests and challenges of the modern world order.

It is shown that political component becomes of paramount importance in the process of the new model of relations between Ukraine and Poland developing. The intensity of political relations is ensured at the diplomatic, intergovernmental, inter-parliamentary levels, in contacts between the Presidents and public associations. Development in the political sphere between the two countries began at the end of 1991. On January 4,1992, diplomatic relations between Ukraine and the Republic of Poland were established. Further steps in the deepening of interstate relations were official visits of states representatives consolidating the equality of partnership. It is emphasized on the dynamism, and progress of the Ukraine-Poland interaction due to the concurrence of the political interests of the neighboring states, their deep historical and cultural ties. Despite the complexity of modern Ukraine-Poland relations, their positive dynamics persist, and taking into account the uniformity of the strategies of Ukraine 
and Poland, it depends, to a large extent, on the preservation and strengthening of political contacts, political dialogue, and the success of the reform policy in Ukraine.

It is determined that the economic relations concerning the realization of the geoeconomic potential of both states occupy a prominent place in the general format of Ukraine-Poland cooperation. In this respect, external economic relations are being built on two main levels: the improvement of the forms of cooperation, their modernization and participation in the integration processes. The formation of a new model of Ukraine-Poland economic relations implies their intensification as a means of supporting national economies and focus on joining the European-world community, maximizing the benefits of economic globalization. In addition, it is proved that the security and defense issue takes more and more priority in UkrainePoland cooperation.

Keywords: Ukraine, the Republic of Poland, relations, cooperation, foreign policy 